\title{
Dissolved silicate retention and transport in cascade reservoirs in Karst area, Southwest China
}

\author{
Fushun Wang ${ }^{\mathrm{a}, *}$, Yuanxiu Yu ${ }^{\mathrm{b}}$, Congqiang Liu ${ }^{\mathrm{c}}$, Baoli Wang ${ }^{\mathrm{c}}$, Yuchun Wang ${ }^{\mathrm{d}}$, Jin Guan $^{\mathrm{c}}$, Hangyuan Mei ${ }^{\mathrm{a}}$ \\ a Applied Radiation Institute, School of Environmental and Chemical Engineering, Shanghai University, Shangda Road 99, Baoshan, Shanghai 200444, China \\ b State Key Laboratory of Urban and Regional Ecology, Research center for Eco-Environmental Science, Chinese Academy of Sciences, Beijing 100085, China \\ c Laboratory of Environmental Geochemistry, Institute of Geochemistry Chinese Academy of Sciences, Guiyang 550002, China \\ d Department of Water Environment, China Institute of Water Resources and Hydroelectric Power Research (IWHR), Beijing 100038, China
}

\section{A R T I C L E I N F O}

\section{Article history:}

Received 9 March 2009

Received in revised form 26 October 2009

Accepted 11 January 2010

Available online 8 February 2010

\section{Keywords:}

Dissolved silicate

Retention

Cascade reservoir

Wujiang river

\begin{abstract}
A B S T R A C T
Presently, the fluvial fluxes of Dissolved silicate (DSi) by many famous rivers in the world have been reported significantly decreased in the past several decades. DSi retention by river damming hence becomes a great concern. In this study, the impact on DSi retention and transport by cascade reservoirs in the Karst area were investigated. Based on the monitoring data for four seasons, budget of DSi in these reservoirs were calculated. Results showed that, only the downstream eutrophic Wujiangdu reservoir (WJD) was the sink for DSi, with a value of ca. $3.5 \mathrm{kT}$ DSi trapped annually. The new Hongiiadu reservoir (HID) in the headwater area revealed to be an important source for DSi. Both Dongfeng (DF) and Suofengyin (SFY) reservoirs also released more DSi to the downstream than entering them. The great discrepancy of DSi source and sink effects among these reservoirs indicates that, (i) DSi was obviously taken up in summer and spring, and the concentration of DSi could be dropped down to below $30 \mu \mathrm{M}$; (ii) during the period of thermal stratification, the concentration stratification of DSi is also developed along the water column. Possibly DSi releasing from inundation soil and bottom sediment was the important compensation for the silicon depletion in the epilimnion. In the newly constructed reservoirs (e.g. HJD and SFY), the releasing flux of DSi can significantly exceed the assimilating flux by diatom; and (iii) due to the hypolimnion introducing for hydropower operation, water leaving the dam generally had high DSi content, and then masked the DSi taking up in the epilimnion. This process also decreased the ratio of DIN to DSi, mitigating the silicon limiting situation in the downstream.
\end{abstract}

(c) 2010 Elsevier B.V. All rights reserved.

\section{Introduction}

Dissolved silicate (DSi) in natural water is mainly originated from the weathering of silicate-containing minerals in soil and rocks. As a macronutrients required by certain groups of plants, e.g. diatom, DSi plays an important role in sustaining river, coastal and oceanic ecosystems (Jossette et al., 1999; Neal et al. 2005; Koszelnik and Tomaszek 2007). Diatoms, contributing 25\% of the world's entire net primary production (Willén, 1991), are the most important group of planktonic algae in marine ecosystem (Humborg et al., 2000). Beside $\mathrm{N}$ and $\mathrm{P}, \mathrm{DSi}$ is also an essential nutrient to diatoms. In diatoms, DSi is taken up and incorporated into an amorphous form known as biogenic silica (BSi) to construct their cell walls (frustules). The decrease in the supply of DSi has a result in the changes in the ratios of nutrient elements (e.g. Si:N:P), which may cause the shifts in phytoplankton populations in water bodies, allowing the nonsiliceous

* Corresponding author. Tel.: + 8621 66137502; fax: +862166137787. E-mail addresses: fswang@shu.edu.cn (F. Wang), hky_yuyx@163.com (Y. Yu), liucongqiang@vip.skleg.cn (C. Liu), baoliwang@163.com (B. Wang),wangyc@iwhr.com (Y. Wang), guanjin@vip.gyig.ac.cn (J. Guan), meihangyuan@126.com (H. Mei). phytoplankton species to bloom (Conley et al., 2000; Ittekkot et al., 2000). Obviously, due to its indispensability for diatom growth, silicon cycling in hydrosphere is of global significance.

For the reason that almost $80 \%$ of the seaward flux of DSi is transported by river (Tréguer et al., 1995), to monitor the variation of global fluvial flux of DSi then becomes an important scientific task in global change research. However, in the last few decades, human activities have caused enormous changes both in the nature and quantity of nutrient fluxes to oceans (Ittekkot et al., 2000), of which the rapid increases of phosphate and nitrate inputs was well documented (Meybeck 1998; Yan et al., 1999; Liu et al., 2003; Yan et al., 2003; Biggs et al., 2004; Gächter et al., 2004; Duan et al., 2007), but the fluvial flux of DSi was found continuously decreasing in rivers worldwide (Justić et al., 1995; Conley et al., 2000; Humborg et al., 2000; Vörösmarty and Sahagian, 2000; Paul, 2003; Vörösmarty et al., 2003; Neal et al., 2005; Humborg et al., 2006; Duan et al., 2007; Li et al., 2007; Koszelnik and Tomaszek 2007; Roubeix et al., 2007).

As the source, transport and sink characteristics of silicate are distinct from those of nitrogen and phosphorus (Ittekkot et al., 2000), scientists gradually relate the "silicate retention" with the extensive river impounding (Humborg et al., 1997; Conley et al., 2000; Humborg 
et al., 2000; Kelly 2001; Humborg et al., 2002; Teodoru and Wehrli 2005; Teodoru et al., 2006a, b; Koszelnik and Tomaszek 2007). In the study of Jossette et al. (1999), 50\% of incoming silica flux was observed lost in the reservoirs (Jossette et al., 1999). Humborg et al. (2002) also found that reservoir with larger live storage has lower DSi concentration, showing higher silica retention efficiency. Increased diatom production and its subsequent sedimentation are undoubtedly the key reasons responsible for the downstream DSi decline in dammed rivers. However, controversy still exists concerning the "silicon trapping capacity" of reservoirs, specifically from the research reports on Iron Gate I Reservoir on the Danube River (Humborg et al., 1997; Humborg et al., 2000; Friedl et al., 2004; Teodoru et al., 2006a; Teodoru et al., 2006b; Teodoru and Wehrli 2005). McGinnis et al (2006) also ascribed the side bays, not the reservoirs itself, as the important silicon trap (McGinnis et al., 2006). Beside, in some reservoirs in the Karst area, the phenomenon of strong silicon assimilating had been observed in the epilimnion, but the DSi concentrations in releasing water of reservoir were still obviously higher than that in the epilimnion, possibly compensated from sediment (Wang, personal communication).

Biogenic silica (BSi, mainly consisting of diatoms frustules) trapping generally is efficient in natural lakes, especially in eutrophic lakes. Dams convert a river into an artificial lake, increasing water residence times and often improving light conditions in the water column giving the preconditions for algal growth, including diatoms (Humborg et al., 2008). Thus, diatom blooms behind dams and subsequent sequestration of BSi in the reservoirs sediments would be responsible for the DSi decrease in the downstream. Although dissolved silicon retention in reservoirs and lakes has been affirmed by scientists, more attention is still needed when evaluating the "damming effect" on DSi of a specific dammed river, due to the large discrepancies among reservoirs, (i.e. geological settings, running style, hydrological retention time, and nutrient stratus), as mentioned above.

For instance, in the Karst area, southwest China, bedrocks universally consisted of carbonates, not the silicate rocks. Thus, DSi in river water should have the source mainly from the weathering of silicate-containing minerals in soil, and accordingly have lower concentrations compared with that in rivers flowing across silicate rocks. Furthermore, owing to the strong chemical weathering and the large river slope in this area, the relief had been incised into many deep canyons, which are also extremely advantaged for hydropower exploitation. As a result, reservoirs in this area, generally have the characteristics of high energy density, deep water column and short hydrological retention time. Consequently, the main objectives of the present study are to investigate the transport and retention of DSi in a serial of cascaded reservoirs on Wujiang river in the Karst area, southwest China. Firstly, the cumulative effect on DSi cycling in cascaded reservoirs was discussed; secondly, how the special releasing style of the deep reservoirs (bottom water releasing) affects the DSi trapping was also the concern; and finally, the impact of dam construction on the silicon export of river in this area was evaluated.

\section{Study area and methods}

\subsection{Study area}

Wujiang River, originated from the Wumeng Ranges on the YunnanGuizhou Plateau, is the largest tributary of Changjiang River in the upper reaches and ends at Fuling City where it joins the Changjiang River. It has a total length of $1,037 \mathrm{~km}$ and a drainage area of $88,267 \mathrm{~km}^{2}$. It is also the largest river in Guizhou Province with a total length of $874 \mathrm{~km}$, an area of $66,849 \mathrm{~km}^{2}$ and a mean water discharge of $1690 \mathrm{~m}^{3} / \mathrm{s}$ (Han and Liu 2004; Yu et al., 2008) (Fig. 1).

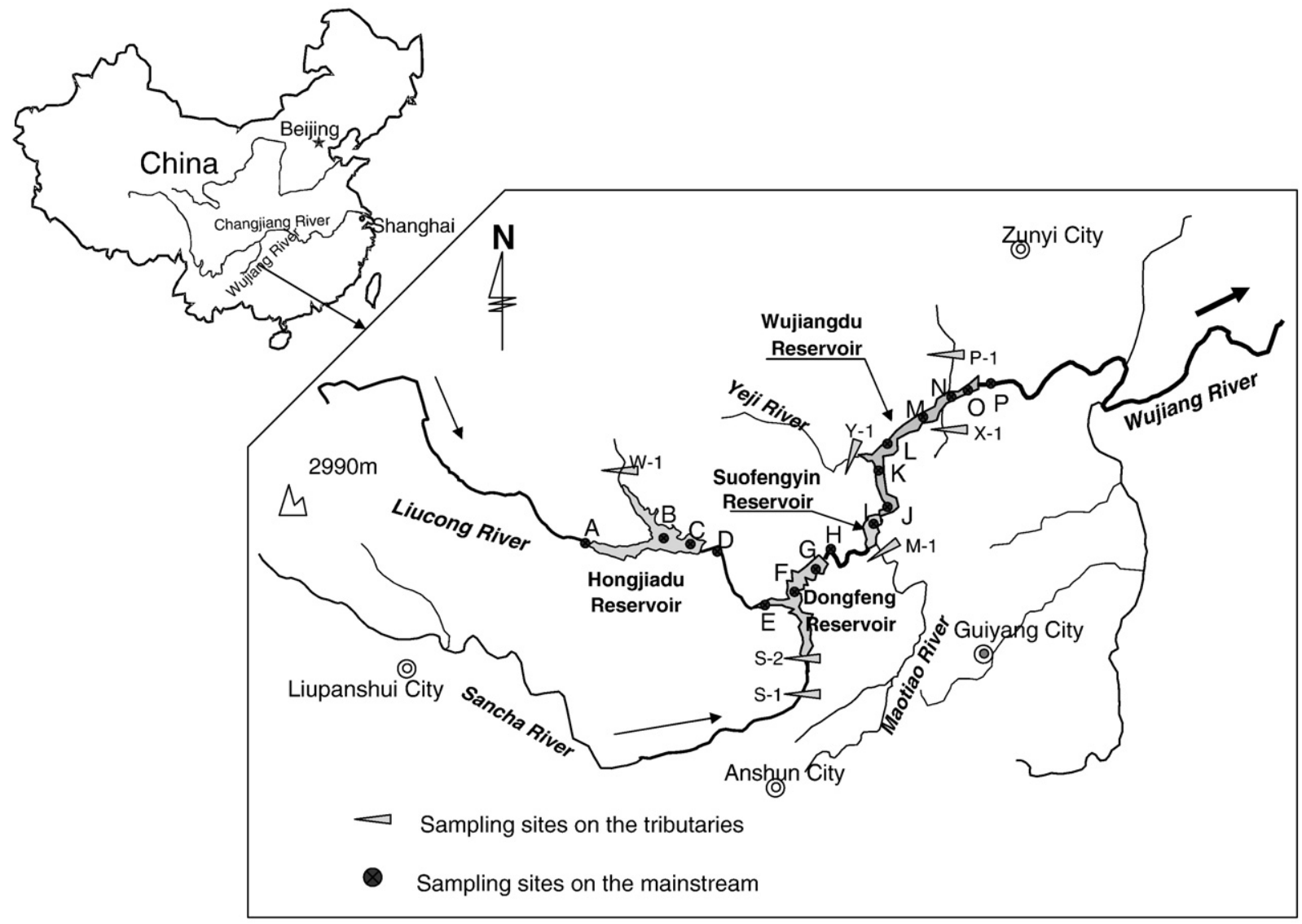

Fig. 1. Map showing the sampling locations. 
The Wujiang River drainage is located in Karst areas of Guizhou Province. The altitudes of the Wujiang river catchments are about $1500 \mathrm{~m}$ in its upper reach and about $500 \mathrm{~m}$ in its lower reach. The annual precipitation in this area ranges from 1100 to $1300 \mathrm{~mm}$, and the precipitation from May to October accounts for about $75 \%$ of the total annual precipitation. Average annual temperature there is $12.3^{\circ} \mathrm{C}$, with the extreme temperatures of $35.4^{\circ} \mathrm{C}$ in summer and 10.1 below zero ${ }^{\circ} \mathrm{C}$ in winter. The coldest month appears in January with an average of $3.5^{\circ} \mathrm{C}$, and in July, the hottest month, the average temperature is $26^{\circ} \mathrm{C}$. Along the upper reaches of the Wujiang River catchment are developed Permian and Triassic carbonate rocks and coal-bearing formations, with minor basaltic igneous rocks. In the middle reaches of the Wujiang River are widely distributed Permian and Triassic limestone, dolomitic limestone and dolomites, while in the lower reaches are mainly distributed carbonate rocks, shale, sands shale and siltstones (Han and Liu 2004).

The Wujiangdu reservoir, Dongfeng reservoir, Hongjiadu reservoir and Suofengying reservoir are all situated on the middle and upper reaches of the Wujiang River, and were impounded in 1979, 1994, 2004 and 2006, respectively. By the year 2006, the reservoirs had been operated for 28 years, 13 years, 3 years and 0 years, respectively. The main features of these reservoirs are described in Table 1.

\subsection{Sampling and methods}

\subsubsection{Sampling}

Water sampling was conducted in April, July and October 2006 and January 2007, which stand for seasons of spring, summer, autumn and winter, respectively. The sampling stations are indicated in Fig. 1. For sampling sites on the tributaries, water was taken $0.5 \mathrm{~m}$ under water surface. Sampling on the mainstream was more complicated because water levels in the reservoirs varied seasonally. In each reservoir, samples of the inflow water and its outflow were collected $0.5 \mathrm{~m}$ under water surface, while water sampling along the water profile were carried out in the central part of the reservoir using a Niskin bottle. For inflow water sampling, we traced to the sampling sites where the basic riverine characteristics are, e.g. rapid velocity of flow, shallow water depth, and turbulent flow. For downstream reservoir, we directly took the releasing water from upper reservoir as the incoming water. In Suofengying reservoir, we didn't collect samples along the water column except surface water samples. This is because that during our sampling season, this reservoir was still under construction, and was starting to impound water.

\subsubsection{Methods}

The $\mathrm{pH}$, and temperature were measured at the sampling sites with a portable $\mathrm{pH}$ and salt conductivity meter. $\mathrm{HCO}_{3}^{-}$was titrated with $\mathrm{HCl}$ in situ.

Water samples were filtered through a $0.45 \mu \mathrm{m}$ polycarbonate membrane immediately after sampling and stored in $50 \mathrm{ml}$ plastic bottles in a cool box. Anion $\mathrm{NO}_{3}^{-}$was measured by ion chromatography. The concentrations of dissolved silicon were measured by ICP-OES. Analytical errors were less than $5 \%$ for $\mathrm{NO}_{3}^{-}$and dissolved silicon determination.

Table 1

The main characteristics of the reservoirs in the studied area.

\begin{tabular}{|c|c|c|c|c|}
\hline Item & Hongjiadu & Dongfeng & Suofengying & Wujiangdu \\
\hline Running age (till 2006) (a) & 3 & 13 & 0 & 28 \\
\hline Normal water level (m) & 1140 & 970 & 837 & 760 \\
\hline $\begin{array}{l}\text { Total storage capacity } \\
\qquad\left(10^{6} \mathrm{~m}^{3}\right)\end{array}$ & 4917 & 1025 & 201 & 2140 \\
\hline $\begin{array}{l}\text { Average annual discharge } \\
\left(\mathrm{m}^{3} / \mathrm{s}\right)\end{array}$ & 155 & 345 & 395 & 502 \\
\hline Reservoir area $\left(\mathrm{km}^{2}\right)$ & 80.5 & 19.7 & 5.7 & 47.5 \\
\hline Height of dam (m) & 179.5 & 168 & 115.8 & 165 \\
\hline $\begin{array}{l}\text { Hydrological retention time } \\
\text { (a) }\end{array}$ & 1 & 0.1 & 0.016 & 0.14 \\
\hline
\end{tabular}

Hydrological data (water discharges) were provided by Guizhou Bureau of Hydrology, and partly by the administrative offices of local reservoirs. Based on this data, DSi mass load is estimated by means of the following procedure: DSi concentrations of the sampling month were multiplied with the sum of the water discharges of the sampling month, and one month before and after it. Contribution from the precipitation is not included in this estimate. This is because that, the direct precipitation on the water area of HJD reservoirs was less than $3 \%$ of its total incoming water, and just $0.3 \%, 0.1 \%$ and $0.7 \%$ in DF, SFY and WJD reservoirs, respectively. Furthermore, DSi concentration in precipitation is generally very low (Yu, 2008). Also, no flood discharge occurred by these reservoirs during our sampling year. As a result, dissolved silicon loads calculation is reasonable, just based on the discharge of incoming and releasing water.

Average concentration of DSi is calculated by the following Eq. (1).

$[\mathrm{DSi}]_{\text {average }}=\sum\left([\mathrm{DSi}]_{i} \times Q_{i} / \mathrm{Q}\right)$.

where, $[D S i]_{i}$ is the concentration of DSi in each season $(\mu M)$; $Q_{i}$ is the water discharge of each season at each site $\left(10^{6} \mathrm{~m}^{3}\right)$; and $\mathrm{Q}$ is the total water discharge of the sampling year at each site $\left(10^{6} \mathrm{~m}^{3}\right)$.

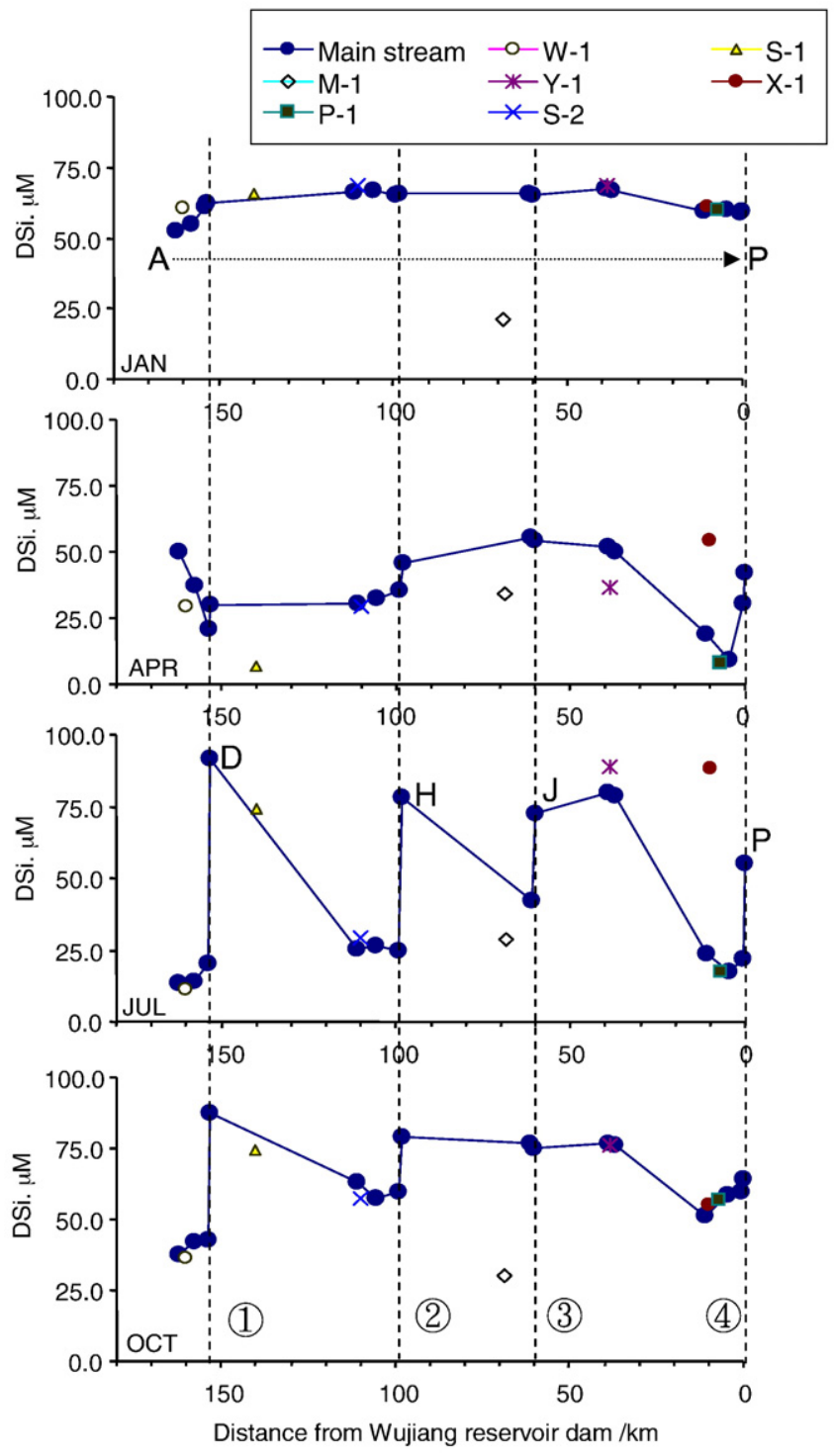

Fig. 2. Seasonal variations of DSi in surface water along the Wujiang. Legends (from A to P) represent the sampling sites on the mainstream, see Fig. 1. 2,3,4, stand for the locations of the dams of Hongjiadu, Dongfeng, Suofengyin, and Wujiangdu reservoirs, respectively. 


\section{Results}

\subsection{Variations of water quality along the cascade reservoirs-river system of Wujiang}

\subsubsection{DSi concentrations}

DSi concentrations had significant variations in different seasons (Fig. 2). In January (winter season), DSi had less fluctuation along the mainstream of Wujiang, ranging from 52 to $67 \mu \mathrm{M}$, with an average of $62 \mu \mathrm{M}$. The presence of dams had no obvious influence on the DSi concentrations entering and leaving reservoirs. However, from April (spring season) to October (autumn season), great discrepancies of DSi concentrations were observed in the outflow of reservoirs (sites D, $\mathrm{H}$, J and P), summer season in particular. Generally, in these seasons, DSi concentrations of the releasing water from the dam would have an abrupt increase, compared with that of the epilimnion of the reservoirs, even that of the inflow water. In fact, in this studied area, due to the cascade exploitation for hydropower, the outflow of upper reservoir has almost become the direct inflow water for the downstream reservoir. Therefore, from Fig. 2, it is clear that DSi was largely absorbed in the epilimnion and re-increased in the releasing water. The exceptional differences between the DSi concentration of epilimnion and that of outflow occurred in summer season, and no obvious difference could be observed in winter. Horizontally, this difference reached its maximal values in Hongjiadu, followed by Dongfeng, Suofengyin and Wujiangdu. For instance, in July, the DSi in epilimnion of Hongjiadu was $20.0 \mu \mathrm{M}$, but in its outflow, concentration of DSi was $91.5 \mu \mathrm{M}$. The difference is $71.5 \mu \mathrm{M}$. At the same time, these differences in Dongfeng, Suofengyin and Wujiangdu, were 54, 30 and $32 \mu \mathrm{M}$, respectively (Fig. 2). By means of discharge weighted, the annual average of DSi in the incoming and releasing water had a range of $27.5 \mu \mathrm{M}$ to $73.1 \mu \mathrm{M}$, with an average of $57.6 \mu \mathrm{M}$ (Table 2).

\subsubsection{Water temperature, $\mathrm{pH}, \mathrm{HCO}_{3}^{-}$and $\mathrm{NO}_{3}^{-}$concentrations}

Basically, temperature and $\mathrm{pH}$ in the surface water in our sampling seasons kept a similar trend along the mainstream of the Wujiang (Fig. 3). In winter, river water was well mixed, and water temperature had less variation in the river course, but $\mathrm{pH}$ had small decreases above and below the dams of Dongfeng and Wujiangdu reservoirs. From spring to autumn, the phenomenon of "cold water releasing" from the dams was obvious. Such as, the maximal temperature difference between epilimnion and outflow could reach to $8{ }^{\circ} \mathrm{C}$ in Wujiangdu reservoir, in July. $\mathrm{pH}$ in the releasing water of reservoirs generally had lower values than that in their epilimnion (Fig. 3). Besides, both $\mathrm{pH}$ and temperature in the water released from the upper reservoir would gradually increase during its transport down along the river course of the downstream reservoir.

Due to the widespread carbonate rocks in the studied area, the $\mathrm{pH}$ of river water ranges from 7.1 to 8.95 , with an average value of 8.06. As a result, the dissolved inorganic carbon (DIC) in water should be dominated by $\mathrm{HCO}_{3}^{-}$, which accounts for about $90 \%$ of the total DIC (Yu et al., 2008). As the major anion, $\mathrm{HCO}_{3}^{-}$generally accounts for more than $70 \%$ of total anions in river water in this area. Different from $\mathrm{DSi}, \mathrm{HCO}_{3}^{-}$concentrations in the mainstream had less variation in January and April. In July, $\mathrm{HCO}_{3}^{-}$concentrations had obvious increase during the transport of river water downward, and the difference reached to $0.74 \mathrm{mM}$ between that of incoming water of Hongjiadu and the outflow of Wujiangdu (Fig. 4). Compared with that in epilimnion of reservoirs, DIC concentrations in water discharged from reservoirs generally were higher, particularly in July and October. Concentrations of $\mathrm{NO}_{3}^{-}$had a range from 0.05 to $0.34 \mathrm{mM}$, with an average value of $0.19 \mathrm{mM}$. In July and October, $\mathrm{NO}_{3}^{-}$generally had higher concentrations than that in April and January.

\subsection{3. $\mathrm{NO}_{3}^{-}$:DSi ratios}

DIN (dissolved inorganic nitrogen) is the sum of ammonia, nitrite, and nitrate. In Wujiang river, nitrate generally is more than $90 \%$ of the DIN (Zhu, 2005). Consequently, here $\mathrm{NO}_{3}^{-}$:DSi ratios were used to evaluate the constraints of ecological stoichiometry, due to the possible change of essential nutrients in cascade reservoirs. From October to January, $\mathrm{NO}_{3}^{-}$:DSi ratios have less variation along the mainstream (Fig. 5), though in October, it almost has a half decrease in the discharged water of Hongjiadu reservoir. In general, a decrease in $\mathrm{NO}_{3}^{-}$:DSi ratios can be always observed in the outflow of the studied reservoirs from April to July. In April, the ratios showed a trend to increase from the incoming river to central part of the Hongjiadu reservoir, and gradually to decrease till Suofengying reservoir, from where to Wujiangdu reservoir, $\mathrm{NO}_{3}^{-}$:DSi ratios had an obvious increase, but with a sharp fall in its outflow (Fig. 5). In July, $\mathrm{NO}_{3}^{-}$: DSi ratios had the highest value in head water, and then approximately kept a decline trend downwards the river course.

\subsection{Seasonal variations of $\mathrm{DSi}, \mathrm{HCO}_{3}^{-}, \mathrm{pH}$ and water temperature inner the reservoirs}

In the water column, $\mathrm{DSi}, \mathrm{HCO}_{3}^{-}, \mathrm{pH}$ and water temperature also had seasonal and vertical variations. In Fig. 6, DSi concentrations generally were higher in deep water. The lowest concentration of DSi occurred in epilimnion in July, while in January it reached to its highest value. Generally, as shown in Fig. 6, for each season DSi in

Table 2

Budget of dissolved silicate load in the studied area.

\begin{tabular}{|c|c|c|c|c|c|c|c|c|}
\hline Reservoirs & Sites & Input/output & $\begin{array}{l}\text { DSi average } \\
\text { concentration } \mu \mathrm{M}^{\mathrm{a}}\end{array}$ & Si flux. ton/a & Total Si input flux. ton/a & Total Si output flux. ton/a & Net flux. ton/a & Trapping or releasing rate $\%$ \\
\hline \multirow[t]{3}{*}{ HJD } & W-1 & Input & 27.5 & - & - & & & \\
\hline & A & Input & 30.8 & - & & & & \\
\hline & $\mathrm{D}$ & Output & 70.3 & 3985 & & 3985 & - & - \\
\hline \multirow[t]{3}{*}{ DF } & $\mathrm{D}$ & Input & 70.3 & 3985 & 11,212 & & & \\
\hline & S-1 & Input & 59.9 & 7227 & & & & \\
\hline & $\mathrm{H}$ & Output & 73.0 & 11,825 & & 11,825 & 612 & 5.46 \\
\hline \multirow[t]{3}{*}{ SFY } & $\mathrm{H}$ & Input & 73.0 & 11,825 & 12,819 & & & \\
\hline & M-1 & Input & 29.0 & 995 & & & & \\
\hline & $\mathrm{J}$ & Output & 70.0 & 13,753 & & 13,753 & 933 & 7.3 \\
\hline \multirow[t]{5}{*}{ WJD } & $\mathrm{J}$ & Input & 70.0 & 13,753 & 15,182 & & & \\
\hline & Y-1 & Input & 72.5 & 702 & & & & \\
\hline & $\mathrm{X}-1$ & Input & 73.1 & 522 & & & & \\
\hline & P-1 & Input & 31.0 & 205 & & & & \\
\hline & $\mathrm{P}$ & Output & 55.7 & 11,724 & & 11,724 & -3458 & -22.8 \\
\hline
\end{tabular}

-: not estimated.

a Average concentration of DSi was the sum of seasonal discharge weighted DSi concentrations. 


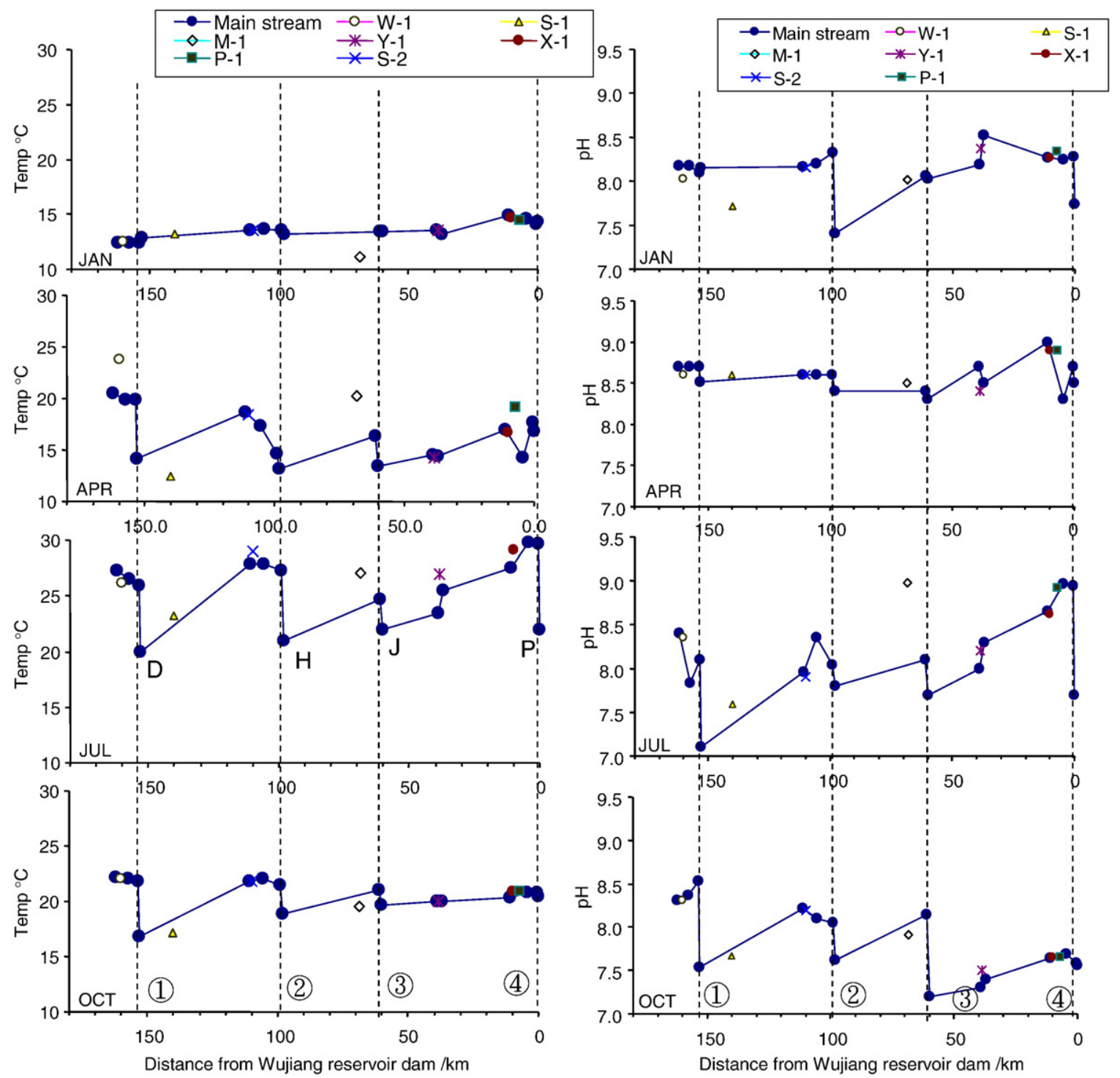

Fig. 3. Seasonal variations of water temperature and $\mathrm{pH}$ in surface water along the Wujiang. Legends are the same as in Fig. 2.

water below $20 \mathrm{~m}$ in depth had obviously higher concentrations than that in epilimnion, except in winter DSi concentration had less variations along the water column, with an average ca. $60 \mu \mathrm{M}$ for HJD, DF and WJD reservoirs, indicating a well mixing condition. However, in WJD reservoir, the lowest values of DSi in April were observed to have appeared in the water zone below 10 to $20 \mathrm{~m}$ in depth, and in other seasons it was in the epilimnion.

Similar to that of DSi, the distribution of $\mathrm{HCO}_{3}^{-}$concentration along the water column showed the trend to decrease from the epilimnion to hypolimnion (Fig. 7). In April, $\mathrm{HCO}_{3}^{-}$concentration had the highest values and also had no variation along the water column. From July to October, concentrations of $\mathrm{HCO}_{3}^{-}$were systematically lower than that in January and April. Both in HJD and in DF reservoirs, large differences of $\mathrm{HCO}_{3}^{-}$ concentration between epilimnion and hypolimnion can be observed from July to January. However, in the WJD reservoir, $\mathrm{HCO}_{3}^{-}$concentration kept the stable values in each season along the water column (Fig. 7).

Water temperature is an important index of the mixing status of water. In Fig. 8, it is clear that from April, temperature gradient started to form in these three reservoirs and the stratification of water temperature could persist from July to October. In winter (January), the water was well exchanged vertically in reservoirs, indicated by the consistent water temperature along the water columns (Fig. 8).
The distribution of $\mathrm{pH}$ was something like that of water temperature (Fig. 9). From January to April, pH showed less variation in the vertical profiles of HJD, DF and WJD reservoirs. In the warmer seasons (from April to October), a low pH zone can be formed and kept in the deep water layer in each reservoirs. The lowest value of $\mathrm{pH}$ along the water column could be under 7.2, 7.6, 7.6 in HJD, DF and WJD reservoirs, respectively.

\subsection{Mass balance calculation of DSi in the cascade reservoirs}

For cascade reservoirs, the head water reservoir (such as HJD in this study) generally has over year storage, while the downstream reservoirs have smaller storage capacities, (e.g. both DF and WJD are seasonal storage reservoirs, and SFY is just a daily storage one). So, for HJD reservoir, the volume of releasing water from the dam might reach a balance to its incoming water only in the scale of several years, and in our sampling year, the ratio between output and input water was $79.3 \%$. The ratios were $91.4 \%, 100 \%$ and $95.6 \%$ for DF, SFY and WJD reservoirs, respectively. Here, we use the actual DSi flux to evaluate the DSi budget for our sampling year, in these cascade reservoirs, and the results were listed in Table 2 . We didn't calculate the DSi budget of HJD reservoir, due to the reasons that: (1) the imbalance of water 


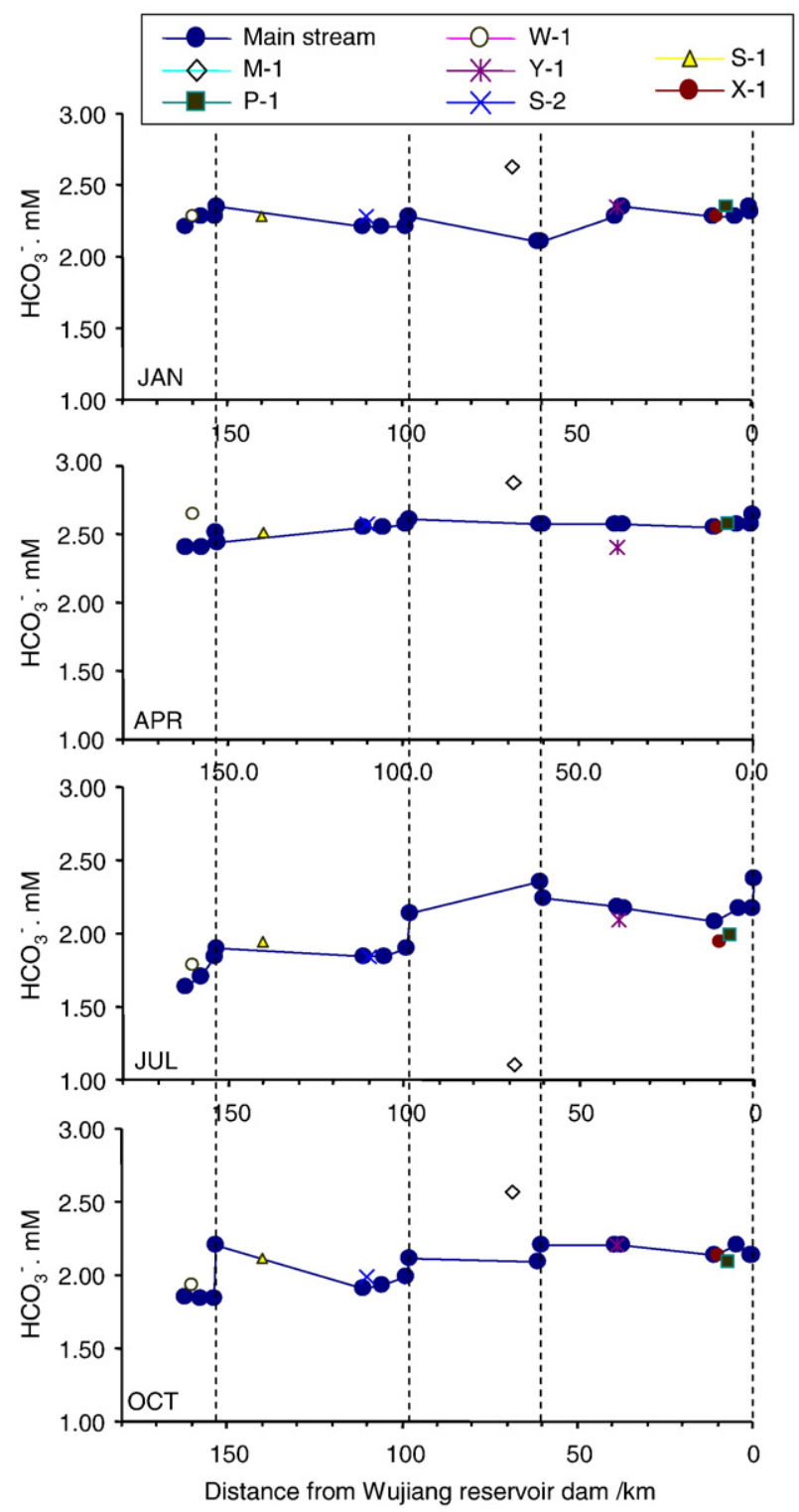

Fig. 4. Seasonal variations of $\mathrm{HCO}_{3}^{-}$concentrations in surface water along the Wujiang. Legends are the same as in Fig. 2.

brought an uncertainty for evaluation; and (2) the increase in water level at site A (input end-member) in high flow season might have an undetermined impact on the homogeneity of water quality there, which possibly influences the estimate of DSi budget, because we used the surface water sampling strategy at site A. However, the output flux of DSi from HJD reservoir can be easily determined, and the value is 3985 ton/a (Table 2). In DF reservoir, there was $5.46 \%$ increase $(612$ ton/a) in the DSi output flux. In SFY reservoir, DSi output flux was 933 ton/a more than its total DSi input flux, with an increase of 7.3\%. According to this estimate, only in WJD reservoir, silicon retention was observed (Table 2). Annually, about 15,180 ton DSi was introduced into WJD reservoir, and the output flux was about 11,724 ton/a, that is, about more than 3,400 ton DSi was trapped in this reservoir, and the trapping rate was $22.8 \%$.

\section{Discussion}

The concentrations of dissolved silicate in world rivers range from 5 to $350 \mu \mathrm{M}$, and in the oceans it has an average of $70 \mu \mathrm{M}$ (Tréguer et al., 1995; Gaillardet et al., 1999; Chen et al., 2002; Duan et al., 2007).

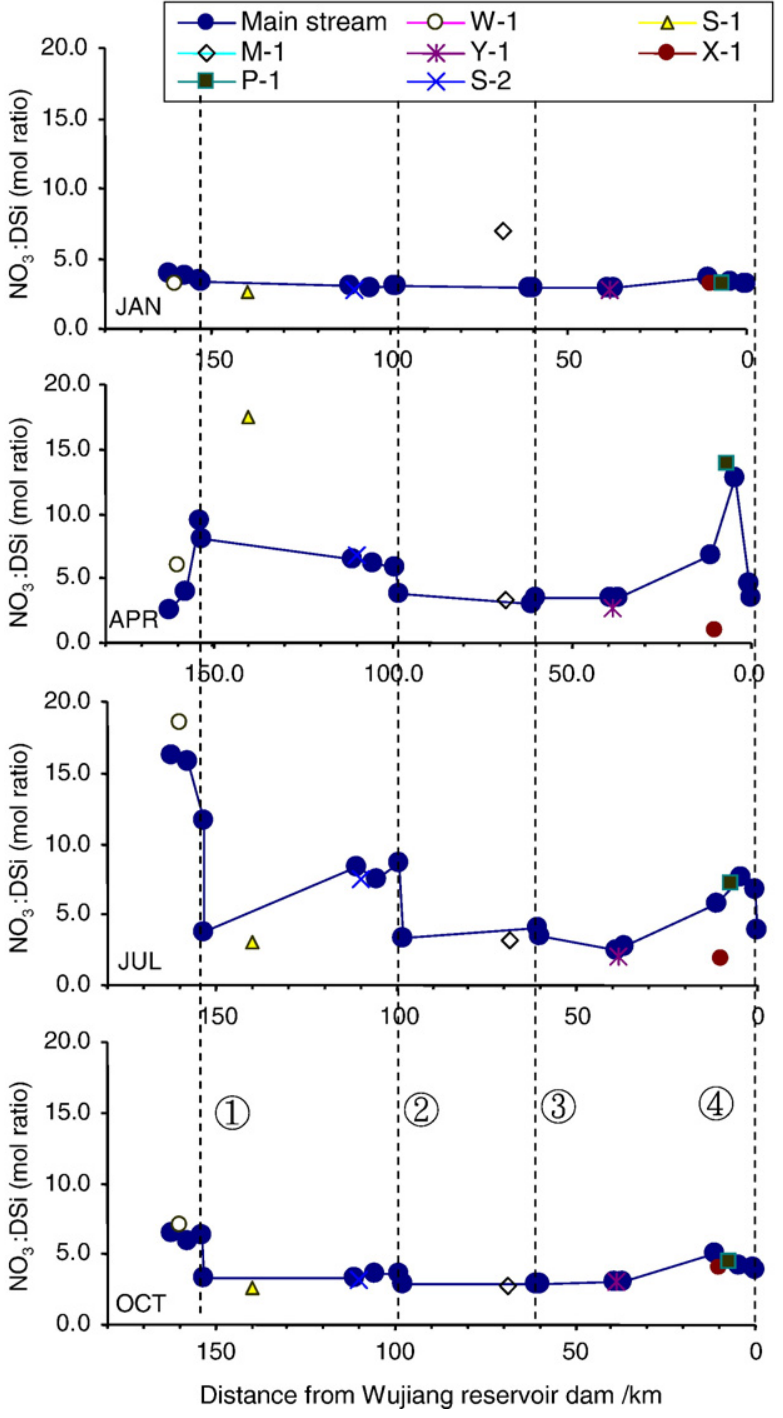

Fig. 5. Seasonal variations of $\mathrm{NO}_{3}^{-}$:DSi ratios in surface water along the Wujiang. Legends are the same as in Fig. 2.

As in our studied area, due to its Karst geological background, DSi in the Wujiang has a range of 7-90 $\mu \mathrm{M}$, which was significantly lower than the average value of global rivers $(216.8 \mu \mathrm{M})$, as well as the DSi gauged at Datong hydrological station in the downstream of Changjiang $(185.7 \mu \mathrm{M})$. Based on the concentration of DSi in the water entering and leaving each reservoir, as well as discharge data, Table 2 gives the brief mass balance for dissolved silicate (DSi) for the studied cascade reservoirs, of which HJD, DF and SFY all showed to be the source of DSi. WJD reservoir was the only sink trapping for ca. $3.5 \mathrm{kT} \mathrm{Si} \mathrm{year}^{-1}$. Presently, it has been accepted that the "artificial lake effect" caused by the dam construction, should be responsible for the silicon retention, which has been observed in impounded rivers worldwide, such as Danube (Humborg et al., 2000), Changjiang (Li et al., 2007; Wang et al., 2007), Seine (Jossette et al., 1999), San River (Koszelnik and Tomaszek 2007), Columbia River in Canada (Matzinger et al., 2007), as well as some smaller rivers (Humborg et al., 2002) (Conley et al., 2000). However, reservoirs in this study showed the reverse effects on DSi, that is, only WJD is the sink for Si, and other three are sources. So, what are the main processes governing the silicon cycle in these reservoirs are still not fully understood.

The main source of DSi to rivers is from the chemical weathering of silicate-containing minerals in soil and rocks. During this process, DSi concentrations can be affected by some factors such as lithology, relief, 

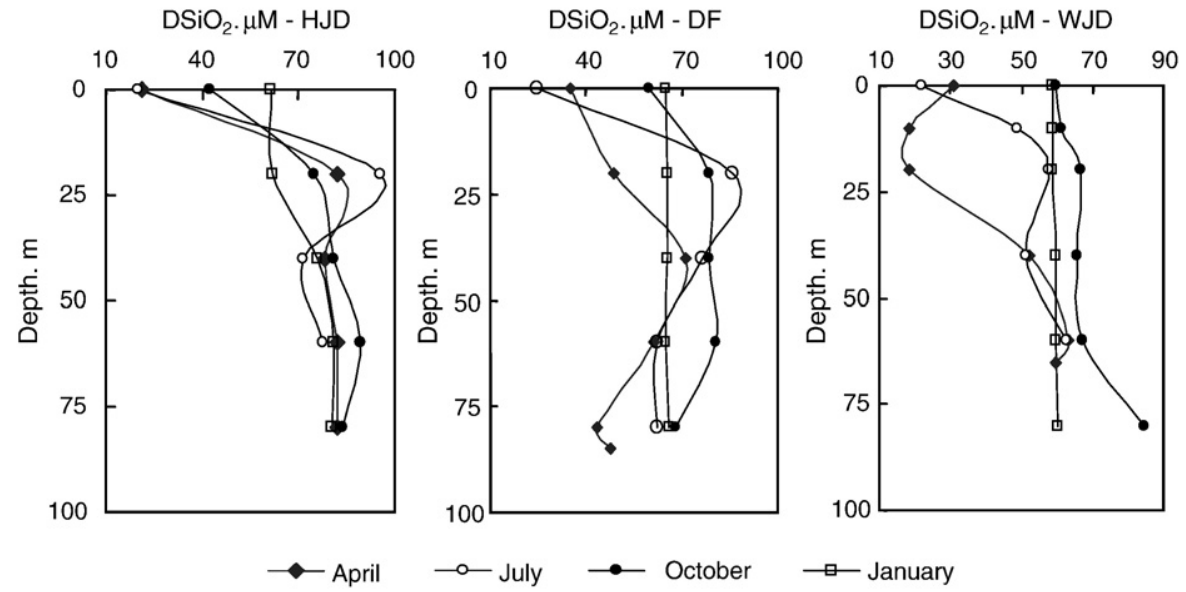

Fig. 6. Seasonal variations of DSi in water columns of Hongjiadu (HJD, site C), Dongfeng (DF, site G) and Wujiangdu (WJD, site O) reservoirs.
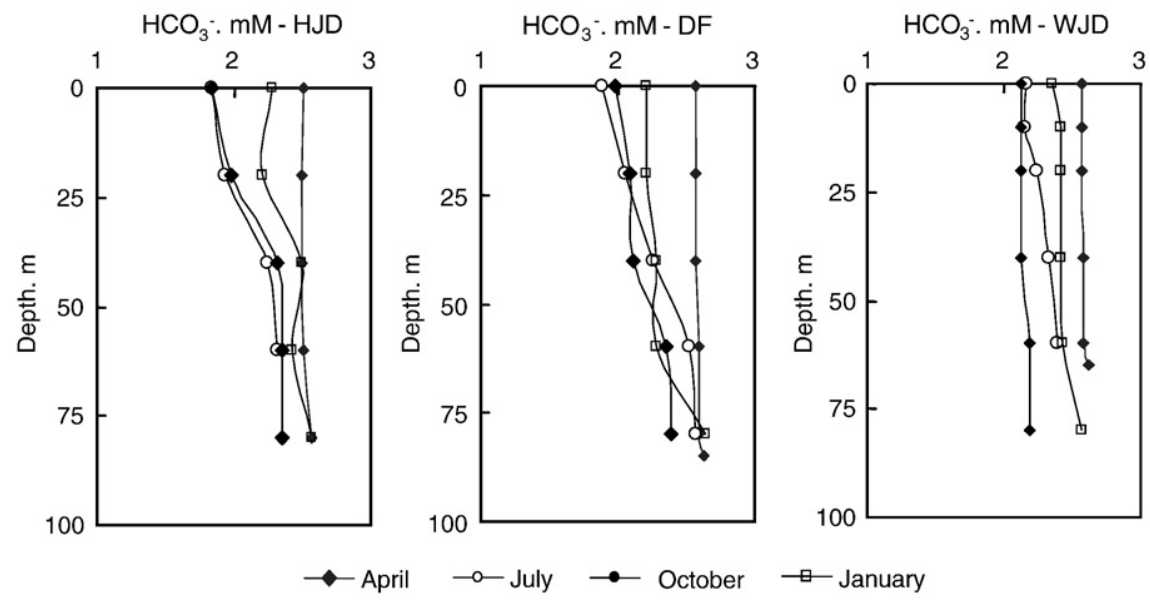

Fig. 7. Seasonal variations of $\mathrm{HCO}_{3}^{-}$in water columns of Hongjiadu (HJD, site C), Dongfeng (DF, site G) and Wujiangdu (WJD, site O) reservoirs.

vegetation, climate variation (Garrels and Mackenzie 1967; Conley et al., 2000; Humborg et al., 2000). However, rocks widely distributing in studied area are mainly composed of carbonate rocks, such as limestone and dolomites. Consequently, DSi from soil should be the main contribution for river Si load, which generally has a consistent input in a short time scale. Also, groundwater and soil water are generally rich in DSi (Hendershot et al. 1992; Lawlor et al. 1998). After inundation, silicate in soil will be released out, in this way to increase the concentration of DSi in overlying water, during the first several years. This phenomenon is similar to the clear-cutting of forests, after which the export of DSi leached from soil can increase by a factor of 2-3 for the first few years (Likens et al. 1970). Furthermore, at an alkaline $\mathrm{pH}$, as in the studied reservoirs, DSi is also favored to be displaced from sorption sites in bottom sediment in the presence of hydroxides (Koszelnik and Tomaszek 2007). This conforms to the observations in this study, i.e. the younger reservoirs (e.g. HJD and SFY) have higher
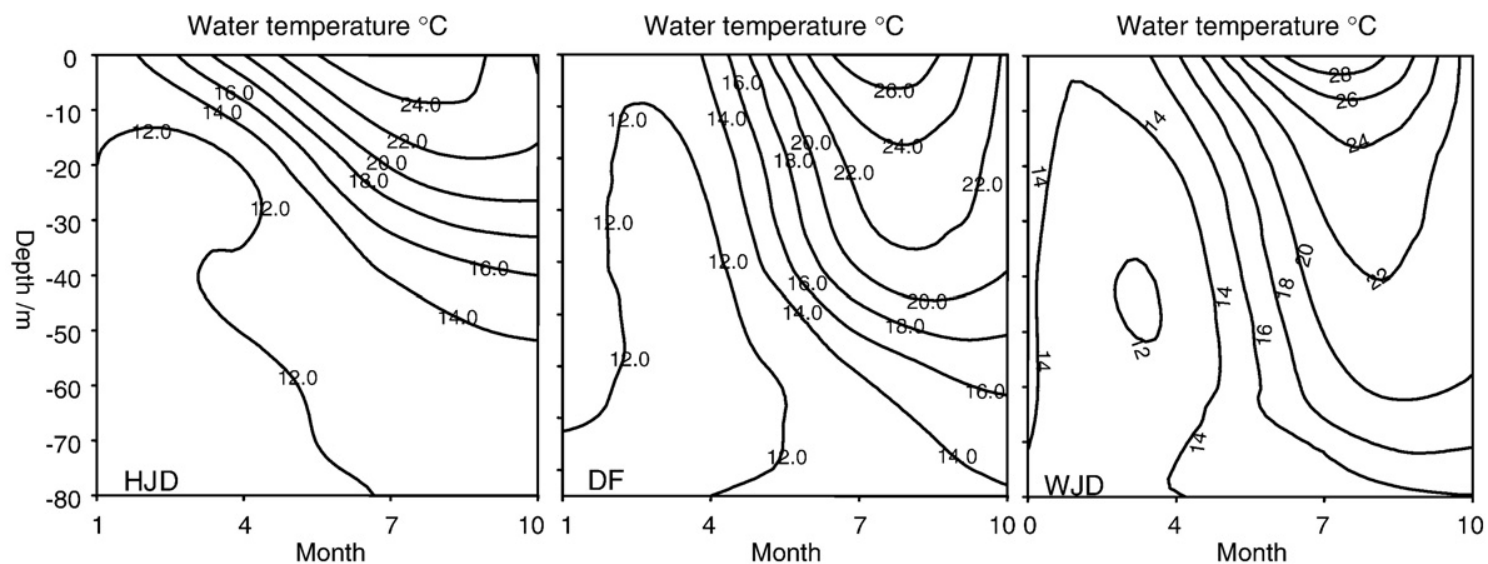

Fig. 8. Contours of seasonal variations of temperature in water columns of Hongjiadu (HJD, site C), Dongfeng (DF, site G) and Wujiangdu (WJD, site O) reservoirs. 

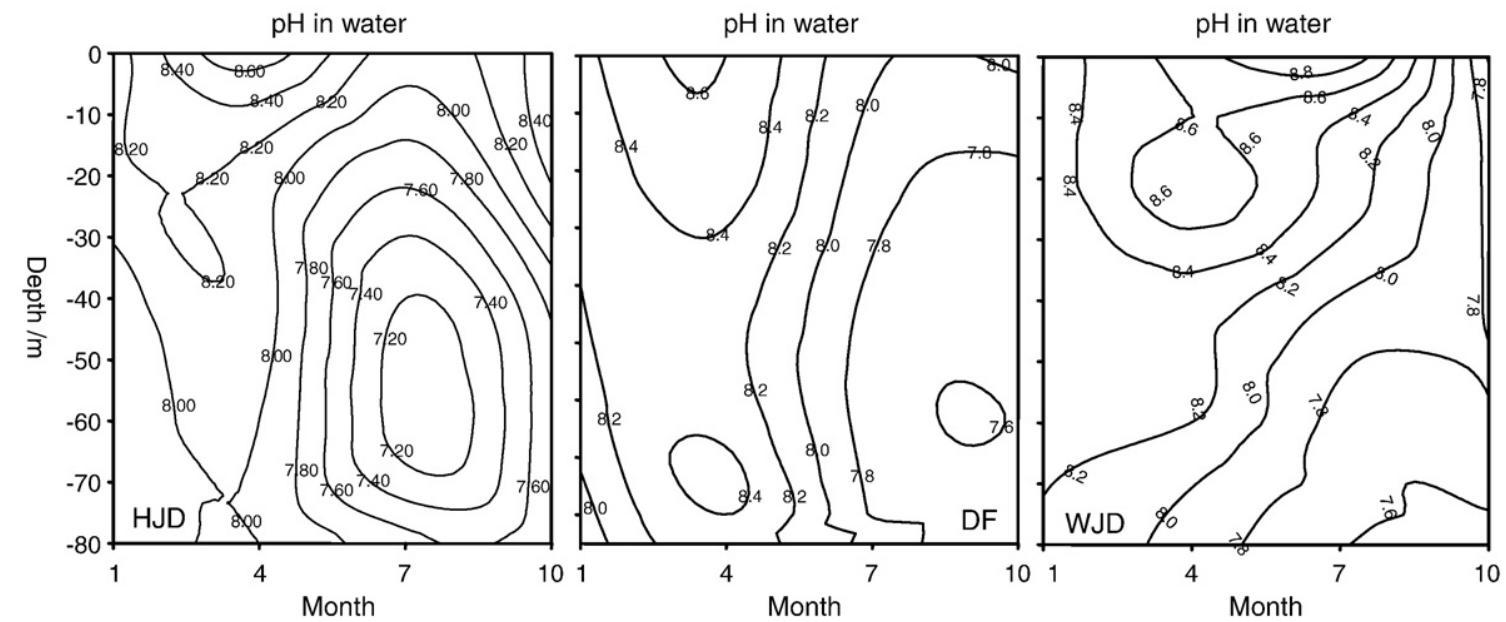

Fig. 9. Contours of seasonal variations of pH in water columns of Hongjiadu (HJD, site C), Dongfeng (DF, site G) and Wujiangdu (WJD, site O) reservoirs.

releasing rate of DSi, and the old one (WJD) has become a sink to DSi (Table 2). The consecutive retaining of suspended solids in the cascade reservoirs may also restricts the DSi flux from sediments in the downstream reservoirs.

Damming converts river into "artificial lake", and generally leads to a decrease in suspended solids and turbidity, an increase in hydrological residence time, thermal stratification and light conditions in the water column. Subsequently, this provides the conditions for autochthonous primary production, including diatoms. In freshwater lakes, phytoplankton preferentially uptakes dissolved $\mathrm{CO}_{2}$ during photosynthesis, which can alter the carbonate equilibrium system in water and remove nutrients (e.g. Si, P, and $\mathrm{N}$ ) from downstream waters. With the continuing photosynthesis process, $\mathrm{CO}_{2}$ concentrations in the euphotic zones can become limited, resulting in the increase of $\mathrm{pH}$ and the decrease in $\mathrm{HCO}_{3}^{-}$. The newly formed organic matters may be decomposed during their sinking process in the water column and on the surface sediments, accompanied by the nutrients re-mineralization and the release of $\mathrm{CO}_{2}$. Water in hypolimnion hence has higher nutrient concentrations and $\mathrm{HCO}_{3}^{-}$, but generally with a lower $\mathrm{pH}$, specifically during the period of thermal stratification. From Fig. 8, it is clear that the studied reservoirs had the similar seasonal thermal stratification, in accordance with which were the distributions of $\mathrm{DSi}, \mathrm{HCO}_{3}^{-}$, and $\mathrm{pH}$ along the water column (Figs. 6,7,9). Algal production has obvious DSi assimilation in epilimnion of each reservoir, from April to October (Fig. 6). This has been confirmed by the negative correlation between $\mathrm{pH}$ and DSi $(N=153, r=-0.63, p<0.01)$ (Fig. 10), i.e. the higher enhanced $\mathrm{pH}$, a result of enhanced primary production, corresponding to the lower

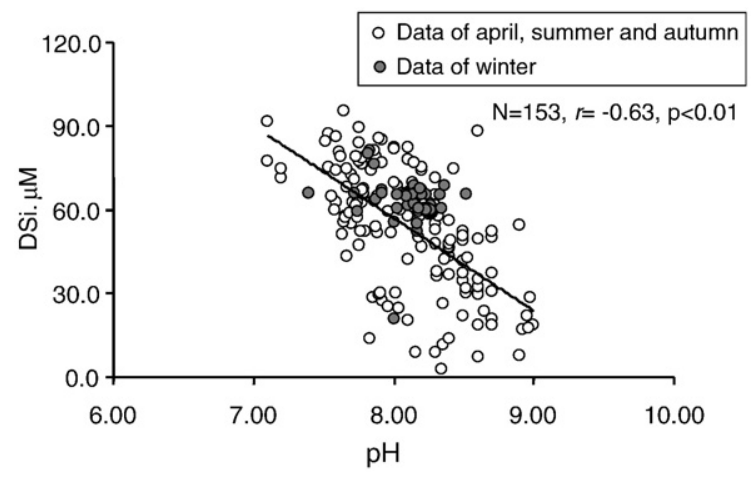

Fig. 10. Dissolved silicate (DSi) concentrations versus $\mathrm{pH}$ variations in the cascade reservoirs of Wujiang basin. For the correlation coefficient calculation, data of winter was not included, because that winter is not the growing season in this area. concentration of DSi. Generally, the retention of DSi in lentic waters is greater in eutrophic lakes, due to the increased diatom production (Conley et al., 1993). Presently, both HJD and DF reservoirs are still in the oligo-trophic condition, and SFY has the meso-trophic status. However, the WJD has become a eutrophic reservoir. As also can be seen in Table 2, about 22\% of incoming DSi was retained in WJD yearly, but the other three reservoirs were the source of DSi. Obviously, large amount DSi releasing from bottom sediment in new reservoirs and the significant taking up by diatom in the downstream eutrophic reservoir made this discrepancy of Si sink/source effects.

Increased diatom production and its sedimentation are thought to be the major processes for DSi loss in dammed river. After blooms, diatoms sink faster than other algae. Slow dissolution limits the diffusion of $\mathrm{Si}$ back to the water column resulting in a net accumulation of silica in sediments (Teodoru et al., 2006a, b). However, the recycling rates of nitrogen $(\mathrm{N})$ and phosphorus (P) are more rapid (Friedl et al., 2004). Furthermore, compounds of nitrogen and phosphorus eliminated may be compensated anthropogenically, but this is not the case for silica (Justić et al., 1995; Jossette et al., 1999; Koszelnik and Tomaszek 2007). Therefore, changes in nutrient ratios and even in the ecosystem in the downstream could be assumed.

The atomic ratio of DIN (this study used $\mathrm{NO}_{3}^{-}$, as discussed above) to DSi is an important factor regulating diatom blooms (Turner et al., 1998; Friedl et al., 2004). The proportion of nonsilicious plankton will be increasing when the value of DIN:DSi is above 1:1. Data in Fig. 5 showed the seasonal variations of DIN:DSi in surface water $(0.5 \mathrm{~m}$ below water surface), along the Wujiang. The ratios were generally higher than the threshold value (i.e. 1:1), suggesting that silicon was the limiting factor for diatom production. In algal bloom seasons (spring and summer), large fluctuations of this ratio could be observed, but in colder seasons (from October to January in this study), it had less variations along the river course (Fig. 5). Besides the DSi assimilation by diatom, large amounts of anthropogenic $\mathrm{N}$ input (e.g. fertilizer application) during the farming season should also be responsible to the high ratio of DIN:DSi. Owing to the supply of DSi from hypolimnion, the ratio of DIN:DSi in water leaving the dam becomes lower. This process could mitigate the situation of silicon limiting in the downstream water to a certain extent.

Another important factor affecting the DSi flux entering and leaving the studied reservoirs is the deep water operation for hydropower from the dam. Unlike other shallow reservoirs (e.g. reservoirs on the Danube River, San river, and Seine river), in which significant Si retention were reported (Jossette et al., 1999; Humborg et al., 2000; Friedl et al., 2004; Koszelnik and Tomaszek 2007), the studied gorge type reservoirs have the dams over $100 \mathrm{~m}$ in height (Table 1). During the period of thermal stratification, a large 
discrepancy of DSi contents between epilimnion and hypolimnion could be observed (Fig. 6). Undoubtedly, the depletion of Si in the epilimnion can be significantly masked by the deep water discharging.

\section{Conclusions}

In the cascade reservoirs on the Wujiang, different source and sink effects of DSi were observed. The newly constructed reservoirs (such as, HJD and SFY) showed to release more DSi than entering them to downstream. However, the older eutrophic downstream reservoir (i.e. WJD) was the only sink for DSi, and ca.22.8\% of incoming DSi was retained in this reservoir. All reservoirs showed a low concentration of DSi in the epilimnion, but a high DSi content could be determined in deep water resulting from the release from bottom sediment. As for the new headwater reservoir (HJD), the early releasing of DSi from inundation soil can remarkably exceed the part of diatom assimilation, leading to net releasing of DSi from the dam. Trophic status of water has obvious impact on DSi retention, such as, in the WJD, which is a eutrophic reservoir, about 3.5 kT DSi was trapped annually.

Due to the deep incision by river on the Karst background, reservoirs on the Wujiang then are quite deep. As a result, the stratification of both water temperature and nutrients are easy to develop. Owing to the hypolimnion operation for hydropower, water leaving the dams hence has higher concentration of DSi, when compared with that in epilimnion, in particular in spring and summer. This process compensates the DSi assimilation in the surface water of reservoir, to a certain extent, and also decreases the ratio of DIN to DSi, which is favorable to diatom production in the downstream.

\section{Acknowledgements}

The authors thank Dr. Xiaolong Liu, and Dr. Hu Ding for their careful assistance in field sampling. We also are grateful to the anonymous reviewers for valuable comments and suggestions on this manuscript. This research was funded by the National Natural Science Foundation of China (No. 40873066 and No. 90610037), the National Basic Research Program of China (973 Program) (No. 2006CB403205), the Shanghai Rising-Star Program (08QA14029) and the Shanghai Leading Academic Disciplines (S30109).

\section{References}

Biggs TW, Dunne T, Martinelli LA. Natural controls and human impacts on stream nutrient concentrations in a deforested region of the Brazilian Amazon basin Biogeochemistry 2004;68:227-57.

Chen JS, Wang FY, Xia XH, Zhang LT. Major element chemistry of the Changjiang (Yangtze River). Chem Geol 2002;187:231-55.

Conley DL, Schelske C, Stoermer EF. Modification of the biogeochemical cycle of silica with eutrophication. Mar Ecol Prog Ser 1993;101:179-92.

Conley DJ, Stålnacke P, Pitk nen H, Wilander A. The transport and retention of dissolved silicate by rivers in Sweden and Finland. Limnol Oceanogr 2000;45(8):1850-3.

Duan SW, Xu F, Wang LJ. Long-term changes in nutrient concentrations of the Changjiang River and principal tributaries. Biogeochemistry 2007;85:215-34.

Friedl G, Teodoru C, Wehrli B. Is the Iron Gate I reservoir on the Danube River a sink for dissolved silica? Biogeochemistry 2004;68:21-32.

Gächter R, Steingruber SM, Reinhardt M, Wehrli B. Nutrient transfer from soil to surface waters: differences between nitrate and phosphate. Aqua Sci 2004;66:117-22.

Gaillardet J, Dupré B, Louvat P, Allègre CJ. Global silicate weathering and $\mathrm{CO}_{2}$ consumption rates deduced from the chemistry of large rivers. Chem Geol 1999;159:3-30.

Garrels RM, Mackenzie FT. Origin of the chemical composition of springs and lakes, in equilibrium concepts in natural water systems. Am Chem Soc Adv Chem Series 1967;67:222-42.

Han GL, Liu CQ. Water geochemistry controlled by carbonate dissolution: a study of the river waters draining karst-dominated terrain, Guizhou Province, China. Chem Geol 2004;204:1-21.

Hendershot WH, Savoie S, Courchesne F. Simulation of stream-water chemistry with soil solution and groundwater flow contributions. J Hydrol 1992;136:237-52.

Humborg C, Ittekkot V, Cociasu A, Bodungen BV. Effect of Danube river dam on Black sea geochemistry and ecosystem structure. Nature 1997;386:385-8.

Humborg C, Conley DJ, Rahm L, Wulff F, Cociasu A, Ittekkot V. Silicon retention in River Basins: far-reaching effects on biogeochemistry and aquatic food webs in coastal marine environments. Ambio 2000;29(1):45-50.
Humborg C, Blomqvist S, Avsan E, Bergensund Y, Smedberg E. Hydrological alterations with river damming in northern Sweden: implications for weathering and river biogeochemistry. Glob Biogeochem Cycles 2002;16(3):1-13.

Humborg C, Pastuszak M, Aigars J, Siegmund H, Mörth CM, Ittekkot V. Decreased silica land-sea fluxes through damming in the Baltic Sea catchment - significance of particle trapping and hydrological alterations. Biogeochemistry 2006;77:265-81.

Humborg C, Smedberg E, Medina MR, Mörth CM. Changes in dissolved silicate loads to the Baltic Sea - the effects of lakes and reservoirs. J Marine Syst 2008;73(3-4): 223-35.

Ittekkot V, Humborg C, Schäfer P. Hydrological alterations and marine biogeochemistry: a silicate issue? Bioscience 2000;50(9):776-82.

Jossette G, Leporcq B, Sanchez N, Phlippon N. Biogeochemical mass-balances (C, N, P, and $\mathrm{Si}$ ) in three large reservoirs of the Seine Basin (France). Biogeochemistry 1999;47:119-46.

Justić D, Rabalais NN, Turner RE, Dortch Q. Changes in nutrient structure of riverdominated coastal waters: stoichiometric nutrient balance and its consequences. Estua Coast Shelf Sci 1995;40:339-65.

Kelly VJ. Influence of reservoirs on solute transport: a regional-scale approach. Hydrol Process 2001:15:1227-49.

Koszelnik P, Tomaszek JA. Dissolved silica retention and its impact on eutrophication in a complex of mountain reservoirs. Water Air Soil Poll 2007;189(1-4):189-98.

Lawlor AJ, Rigg E, May L, Woof C, James JB, Tipping E. Dissolved nutrient concentrations and loads in some upland streams of the English Lake District. Hydrobiologia 1998;377:85-99.

Li MT, Xu K, Watanabe M, Chen ZY. Long-term variations in dissolved silicate, nitrogen, and phosphorus flux from the Yangtze River into the East China Sea and impacts on estuarine ecosystem. Estua Coast Shelf Sci 2007;71:3-12.

Likens GE, Bormann FH, Johnson NM, Fisher DW, Pierce RS. Effects of forest cutting and herbicide treatment on nutrient budgets in the Hubbard Brook watershedecosystem. Ecol Monogr 1970;40:23-47.

Liu SM, Zhang J, Chen HT, Wu Y, Xiong H, Zhang ZF. Nutrients in the Changjiang and its tributaries. Biogeochemistry 2003;62(1):1-18.

Matzinger A, Pieters R, Ashley K, Lawrence GA, Wüest A. Effects of impoundment on nutrient availability and productivity in lakes. Limnol Oceanogr 2007;52(6): 2629-40.

McGinnis DF, Bocaniov S, Teodoru C, Friedl G, Lorke A, Wüest A. Silica retention in the Iron Gate I reservoir on the Danube River: the role of side bays as nutrient sinks. River Res Appl 2006;22(4):441-56.

Meybeck M. The IGBP water group: a response to a growing global concern. Global Change Newsletters 1998;36:8-12.

Neal C, Neal M, Reynolds B, Maberly SC, May L, Ferrier R, et al. Silicon concentrations in UK surface waters. J Hydrol 2005;304:75-93.

Paul L. Nutrient elimination in pre-dams: results of long term studies. Hydrobiologia 2003;504:289-95.

Roubeix V, Rousseau V, Lancelot C. Diatom succession and silicon removal from freshwater in estuarine mixing zones: From experiment to modelling. Estua Coast Shelf Sci 2007;78(1):14-26.

Teodoru C, Dimopoulos A, Wehrli B. Biogenic silica accumulation in the sediments of Iron Gate I Reservoir on the Danube River. Aqua Sci 2006a;68:469-81.

Teodoru C, Mcginnis DF, Wüest A, Wehrli B. Nutrient Retention in the Danube's Iron Gate Reservoir. Eos 2006b;87(38):385-400.

Teodoru C, Wehrli B. Retention of sediments and nutrients in the Iron Gate I Reservoir on the Danube River. Biogeochemistry 2005;76:539-65.

Tréguer P, Nelson DM, Vanbennekom AJ, Demaster DJ, Leynaert A. The silica balance in the world ocean: a re-estimate. Science 1995;268:375-9.

Turner RE, Qureshi N, Rabalais NN, Dortch Q, Justic D, Shaw RF, et al. Fluctuating silicate: nitrate ratios and coastal plankton food webs. Proc Natl Acad Sci 1998;95: 13048-51.

Vörösmarty CJ, Meybeck M, Fekete B, Sharma K, Green P, Syvitski JPM. Anthropogenic sediment retention: major global impact from registered river impoundments. Global Planet Change 2003;39(1-2):169-90.

Vörösmarty CJ, Sahagian D. Anthropogenic disturbance of the terrestrial water cycle. Bioscience 2000;50(9):753-65.

Wang F, Wang Y, Zhang J, Xu H, Wei XG. Human impact on the historical change of $\mathrm{CO}_{2}$ degassing flux in River Changjiang. Geochem Trans 2007;8(7). doi:10.1186/14674866-8-7.

Willén E. Planktonic diatoms - an ecological review. Algological Studies 1991;62: 69-106.

Yan W, Yin C, Zhang S. Nutrient budgets and biogeochemistry in an experimental agricultural watershed in Southeastern China. Biogeochemistry 1999;45:1-19.

Yan W, Zhang S, Sun P, Seitzinger SP. How do nitrogen inputs to the Changjiang basin impact the Changjiang River nitrate: a temporal analysis for 1968-1997. Glob Biogeochem Cycles 2003;17(4):1091. doi:10.1029/2002GB002029.

Yu YX, Liu CQ, Wang FS, Wang BL, Li J, Li SL. Dissolved inorganic carbon and its isotopic differentiation in cascade reservoirs in the Wujiang drainage basin. Chinese Sci Bull 2008;53(21):3371-8

Yu YX. The effects of damming river on biogeochemical cycling of carbon in the middleupper reaches of Wujiang, SW China. Ph.D Dissertation. Graduate School of the Chinese Academy of Sciences 2008.

Zhu J. Effects of dams on the biogeochemical cycles of nutrients in the Wujiang River. Ph.D Dissertation. Graduate School of the Chinese Academy of Sciences 2005. 